There are two possible explanations for the persistence of antibody in spite of treatment in Case 23 (Table IV). Firstly, the stage of gamma-G production may have been reached before the injection was given. Secondly, the $0.5 \mathrm{ml}$. dose of $\mathrm{Rh}$ immune globulin may have been inadequate.

Of interest were the subjects who had evidence of sensitization at delivery, were untreated, and yet became negative for anti-D by six months. If the weak antibody which was found at delivery indicated a primary immune response to the $D$ antigen the subsequent disappearance of the antibody may merely mean that it dropped to a level which was below the sensitivity of our tests. If so, with re-exposure to the $D$ antigen -that is, another $\mathrm{Rh}$-positive foetus, an exaggerated anti-D response typical of a secondary immune reaction may occur. These subjects will be carefully followed in a subsequent pregnancy for evidence of this. In this context, it may be noted that all of the five subjects showing a strong antibody response by the time of delivery (anti-D titre greater than 1:4) were multigravid. These subjects may have been mildly sensitized by a previous pregnancy with a subsequent drop of anti-D to undetectable levels, and during the present pregnancy may have had the exaggerated antibody response to the $D$ antigen typical of a secondary immune reaction.

(b) Subjects with No Detectable Antibody at Delivery.-The largest group in this study was the one in which no antibodies were found at delivery. None of the treated subjects and $4.8 \%$ ( 2 of 42 ) of the untreated subjects subsequently developed anti-D. This $4.8 \%$ incidence of sensitization occurring after delivery is lower than reported in comparable series. We have excluded from this category the individuals who were weakly positive for anti-D at delivery, while other series make no mention of them. If they had been included in our series the overall rate of antibody formation in the untreated subjects would have been $14 \%$ (7 of 51 ).

\section{Antenatal Treatment}

The work of Zipursky and Israels (1967) indicates that giving anti-D gammaglobulin intramuscularly during pregnancy is a safe procedure and that the anti-D given has no detrimental effect on the Rh-positive foetus. With this encouragement, we are now embarking on an antenatal treatment programme.

All Rh-negative women who have $\mathrm{Rh}$-positive husbands and who have no detectable anti-D will be given $0.5 \mathrm{ml}$. $(145 \mu \mathrm{g}$. anti-D) of Rh-immune globulin at 34 weeks' gestation. A further $0.5 \mathrm{ml}$. will be administered on delivery of an ABOcompatible Rh-positive infant. This programme will be compared with more conventional treatment with either 0.5 or $1 \mathrm{ml}$. of $\mathrm{Rh}$-immune globulin given only at delivery.

This study was made possible by grant number 321 from the Department of Public Health of the Province of Alberta and the University of Alberta Hospital.

We acknowledge with thanks the assistance of Mrs. G. Schultz and Dr. A. G. Stewart in the preparation of this manuscript.

\section{REFERENCES}

Brit. med. F., 1966, 2, 907.

Buchanan, D. I. (1956). Amer. F. clin. Path., 26, 21.

Buchanan, D. I., and Dierich, K. P. (1965). Transfusion (Philad.), 5, 11. Canad. med. Ass. F., 1967, 97, 1294.

Chown, B. (1967). Personal communication.

Cohen, F., and Zuelzer, W. W. (1964). Vox Sang. (Basel), 9, 75.

Cohen, F., and Zuelzer, W. W. (1964). Vox Sang. (Basel), 9,
Finkelstein, M. S., and Uhr, J. W. (1964). Science, 146, 67.

Freda, V. J., Gorman, J. G., and Pollack, W. (1966). Science, 151, 828. Mollison, P.' L. (1968). Brit. F. Haemat., 14, 1.

Wigzell, H. (1966). ₹. exp. Med., 124, 953 .

Woodrow, J. C., et al., (1965). Brit. med. f., 1, 279.

Zipursky, A., and Israels, L. G. (1967). Canad. med. Ass. F., 97, 1245. Zipursky, A., Pollock, J., Neelands, P., Chown, B., and Israels, L. G. (1963). Lancet, 2, 489.

Zipursky, A., Pollock, J., Chown, B., and Israels, L. G. (1965). Birth Defects, Original Article Series, 1, 84.

\title{
Investigation into the Attenuation of Influenza Viruses by Serial Passage
}

\author{
A. S. BEARE,* M.B., M.C.PATH. ; M. L. BYNOE,* M.B., B.S.; D. A. J. TYRRELL,* M.D., F.R.C.P., M.C.PATH.
}

\begin{abstract}
Cummary : For vaccination live viruses are better than $\checkmark$ dead ones, but live influenza vaccines are difficult to prepare. One influenza $A_{2}$ and two influenza $B$ viruses were passed in series in embryonated eggs. At several stages of their passage they were inoculated into volunteers, and their effects assessed by virus isolations, antibody rises, and clinical reactions. The $A_{2}$ virus and one of the influenza $B$ viruses, both of which had grown readily in embryonated eggs on first isolation, continued to induce human infections and clinical reactions after 30 egg passes. The other influenza $B$ virus acquired enhanced human pathogenicity after three passages from man to man. After adaptation to eggs in which it at first grew reluctantly, its human virulence was appreciably reduced. It underwent no further change during a total of $20 \mathrm{egg}$ passes. There was little convincing evidence of an increased incidence of clinical reactions during the winter seasons, but the numbers of volunteers were too small to draw definite conclusions.
\end{abstract}

* Common Cold Research Unit, Salisbury, Wiltshire.

\section{Introduction}

The use of living influenza viruses as vaccines has many advantages. The vaccines are quickly and painlessly administered as drops or spray and induce a high degree of immunity (Beare et al., 1968). However, many problems arise in their preparation. In our hands the Russian $A_{2}$ virus Iksha failed to infect after a few passes in the laboratory, and this was attributed to the effects of egg passage (Zhdanov et al., 1957; Beare et al., 1967). Burnet and Bull (1943) originally suggested that influenza viruses were inherently genetically unstable and that it might be possible to attenuate them by egg passage so that they could be used as living vaccines. This has now been said in more precise terms by Zhdanov (1967), who maintains that passage in embryonated eggs induces first a rapid loss of human pathogenicity and later a loss of human infectivity. He adds that the number of passes needed for these changes varies rather widely with different virus strains, and that the changes themselves can be detected only in volunteer trials, since there are no reliable laboratory markers by which they can be predicted. Our own subsequent experience with influenza B viruses, however, indicated that these were 
only slowly altered by egg passage and that the method could not be depended on for the production of attenuated mutants.

A systematic study has therefore been made of the effects of egg passage on three human influenza viruses, one of which was an Asian virus and the other two were influenza $B$ viruses with different capacities for growth in embryonated eggs when first isolated.

\section{Materials and Methods}

\section{Viruses}

The $A_{2}$ virus was a live vaccine strain known as $A_{2} /$ Leningrad/ $4 / 65$ and was provided by Professor A. A. Smorodintsev of the U.S.S.R. Academy of Medical Sciences in Leningrad. It had probably had four or five egg passes. After intranasal inoculation of a volunteer it was reisolated in the allantoic cavity of 10-day embryonated leucosis-free eggs. The virus was subsequently passed in series in leucosis-free eggs until 30 passes had been obtained.

B/England/101/62 was isolated accidentally from volunteers in this unit. Two volunteers used as controls were given tissue culture fluid containing no virus. Their nasal washings were given to other volunteers, from whom this virus was then unexpectedly recovered. The virus was maintained by three serial passes from man to man and was stored as nasal washings with the addition of $50 \%$ nutrient broth. In addition, the third human passage was inoculated amniotically into 13-day embryonated leucosis-free eggs in which it grew reluctantly. Later the virus was passed allantoically a further 19 times.

$\mathrm{B} /$ England $/ 13 / 65$ was originally isolated by Dr. P. G. Higgins of the Public Health Laboratory, Cirencester. A stored human throat swab containing this virus was inoculated allantoically into 10-day embryonated leucosis-free eggs, and it grew readily on first isolation. Parallel inocula of low virus dilutions (containing about $10^{6.0}$ egg-infecting doses, EID $_{50}$ ) and of limit dilutions were made in series until 30 passes had been obtained. It was thought that a mutant would be more readily selected by the use of concentrated inocula (Burnet, 1951). Most virus pools in the passage series contained about $10^{9.0} \mathrm{EID}_{50}$ per $\mathrm{ml}$.

The first egg passage of $\mathrm{B} /$ England/101/62 was harvested after 72 hours' incubation at $33^{\circ} \mathrm{C}$. All other egg passages of the three viruses were harvested after 42-48 hours' incubation at $33^{\circ} \mathrm{C}$.

Virus pools were stored in sealed glass ampoules at $-70^{\circ} \mathrm{C}$.

Clinical Observations.-Clinical reactions were graded nil, mild, moderate, or severe according to the standard practice of the unit (Tyrrell, 1963).

Recovery of Virus from Volunteers.-Nasal washings were taken on the second, third, and fourth days after virus had been given to volunteers. These washings were inoculated into primary cultures of monkey kidney cells which were tested for haemadsorption after five days' incubation in a rolling drum at $33^{\circ} \mathrm{C}$.

Antibody Titrations.-Haemagglutination-inhibition (H.I.) tests were performed simultaneously on volunteers' sera obtained before the administration of virus and on those obtained two to three weeks afterwards. Sera were initially treated with cholera filtrate and after twofold dilutions had been made in series, four haemagglutinating doses of virus were added to each serum dilution. The serum-virus mixtures were allowed to interact for one hour at room temperature before the addition of $0.5 \%$ fowl red cells.

\section{Results}

The results of inoculating volunteers with different passes of the three viruses are shown in Tables I-IV. The number of volunteers in each trial with serum H.I. titres below and above 24 is indicated, since this can be expected to give some information on the susceptibility of groups of volunteers to infection. However, it had previously been shown that titres of circulating antibody reflect very imperfectly the degree of human resistance to infection with influenza viruses and that an appreciable incidence of infection could be expected in people with high H.I. titres (Beare et al., 1968). This is particularly well shown in trial 43 (Table II). Of 22 volunteers in this trial, 14 had initial high titres of H.I. antibody, and after administration of virus there were also 14 virus isolations.

TABle I.-Responses of Volunteers to Different Passes of $A_{2} /$ Leningrad/

\begin{tabular}{|c|c|c|c|c|c|c|c|c|}
\hline \multirow[t]{2}{*}{ Trial } & \multirow[t]{2}{*}{ Date } & \multirow{2}{*}{$\begin{array}{c}\text { Virus } \\
\text { Passage }\end{array}$} & \multirow{2}{*}{$\begin{array}{c}\text { Virus } \\
\text { Dose } \\
\left(\text { EID }_{s_{0}}\right)\end{array}$} & \multicolumn{2}{|c|}{$\begin{array}{c}\begin{array}{c}\text { Volunteers } \\
\text { Initial }\end{array} \\
\text { H.I. Titres } \\
\end{array}$} & \multirow{2}{*}{$\begin{array}{l}\text { Virus } \\
\text { Isola- } \\
\text { tions }\end{array}$} & \multirow{2}{*}{$\begin{array}{l}\text { Anti- } \\
\text { body } \\
\text { Rises }\end{array}$} & \multirow{2}{*}{$\begin{array}{l}\text { Clinical } \\
\text { Reac- } \\
\text { tions }\end{array}$} \\
\hline & & & & $\leqslant 24$ & $>24$ & & & \\
\hline 23 & \multirow{5}{*}{\begin{tabular}{|l|} 
Aug. \\
1966 \\
Dec. \\
1966 \\
Sept. \\
1967 \\
Aug. \\
1967 \\
Jan., \\
Feb., \\
1968
\end{tabular}} & $\mathbf{x}$ & $10^{8.0}$ & 5 & 0 & $3 / 5$ & $3 / 5$ & $1 / 5$ \\
\hline 26 & & $\mathrm{XHU} \mathrm{E}_{2}$ & $10^{4.5}$ & 8 & 0 & $5 / 8$ & $7 / 8$ & $7 / 8$ \\
\hline 35 & & $\mathbf{X} \mathbf{H U}_{1} \mathbf{E}_{\mathbf{2}}$ & $10^{5.0}$ & 10 & 2 & $6 / 12$ & $6 / 11$ & $2 / 12$ \\
\hline 34 & & 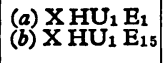 & $\begin{array}{l}10^{5.0} \\
10^{5.0}\end{array}$ & $\begin{array}{l}8 \\
7\end{array}$ & $\begin{array}{l}1 \\
2\end{array}$ & $\begin{array}{l}4 / 9 \\
4 / 9\end{array}$ & $\begin{array}{l}5 / 9 \\
4 / 8\end{array}$ & $\begin{array}{l}0 / 9 \\
1 / 9\end{array}$ \\
\hline 41 & & $X \mathrm{HU}_{1} \mathrm{E}_{30}$ & $10^{5.0}$ & 4 & 2 & $4 / 6$ & $4 / 6$ & $3 / 6$ \\
\hline \multicolumn{4}{|c|}{ Total } & 42 & 7 & $\begin{array}{l}26 / 49 \\
(53 \%)\end{array}$ & $\begin{array}{r}29 / 47 \\
(62 \%)\end{array}$ & $\begin{array}{r}14 / 49 \\
(29 \%)\end{array}$ \\
\hline
\end{tabular}

In Tables I-IV numerators are positive results, denominators are numbers tested. $\mathrm{X}=$ Unknown passage history. $\mathrm{HU}=$ Human pass. $\mathrm{E}=\mathrm{Egg}$ passages. EID $\mathrm{s}_{0}=$ $50 \%$ egg infecting doses. Trials $34(a)$ and $34(b)$ took place at the same time. TABLE II.-Responses of Volunteers to Different Passes of B/England/

\begin{tabular}{|c|c|c|c|c|c|c|c|c|}
\hline \multirow[t]{2}{*}{ Trial } & \multirow[t]{2}{*}{ Date } & \multirow{2}{*}{$\begin{array}{c}\text { Virus } \\
\text { Passage }\end{array}$} & \multirow{2}{*}{$\begin{array}{c}\text { Virus } \\
\text { Dose } \\
\left(\text { EID }_{50}\right)\end{array}$} & \multicolumn{2}{|c|}{$\begin{array}{c}\text { Volunteers. } \\
\text { Initial } \\
\text { H.I. Titres }\end{array}$} & \multirow{2}{*}{$\begin{array}{l}\text { Virus } \\
\text { Isola- } \\
\text { tions }\end{array}$} & \multirow{2}{*}{$\begin{array}{l}\text { Anti- } \\
\text { hndy } \\
\text { Rises }\end{array}$} & \multirow{2}{*}{$\begin{array}{l}\text { Clinical } \\
\text { Reac- } \\
\text { tions }\end{array}$} \\
\hline & & & & $\leqslant 24$ & $>24$ & & & \\
\hline $\begin{array}{l}22 \\
25\end{array}$ & $\begin{array}{l}\text { July } \\
1966 \\
\text { Dec. } \\
1966\end{array}$ & \multirow{8}{*}{$\begin{array}{l}\text { (a) } \mathbf{E}_{3} \\
\text { (b) } \mathbf{E}_{17} \\
\text { (a) } \mathbf{E}_{20} \text { limit } \\
\text { dilution pass } \\
\text { (b) } \mathbf{E}_{20} \text { low } \\
\text { dilution pass } \\
\text { (a) } \mathbf{E}_{20} \text { limit } \\
\text { dilution pass } \\
\text { (b) } \mathbf{E}_{20} \text { low } \\
\text { dilution pass } \\
\mathbf{E}_{30}\end{array}$} & $\begin{array}{c}\text { (a) } 10^{4.4} \\
\text { (b) } 10^{3.4} \\
10^{4.7}\end{array}$ & $\begin{array}{l}4 \\
3 \\
0\end{array}$ & $\begin{array}{l}0 \\
0 \\
8\end{array}$ & $\begin{array}{l}2 / 4 \\
2 / 3 \\
2 / 8\end{array}$ & $\begin{array}{l}1 / 4 \\
2 / 3 \\
1 / 8\end{array}$ & $\begin{array}{l}3 / 4 \\
1 / 3 \\
3 / 8\end{array}$ \\
\hline 23 & $\begin{array}{l}\text { July } \\
1966\end{array}$ & & $10^{6.7}$ & 0 & 2 & $2 / 2$ & $1 / 2$ & $0 / 2$ \\
\hline 31 & $\begin{array}{l}\text { July } \\
1967\end{array}$ & & $\begin{array}{l}10^{5.5} \\
10^{5.5}\end{array}$ & $\begin{array}{l}5 \\
4\end{array}$ & $\begin{array}{l}2 \\
3\end{array}$ & $\begin{array}{l}3 / 7 \\
4 / 7\end{array}$ & $\begin{array}{l}2 / 7 \\
4 / 6\end{array}$ & $\begin{array}{l}5 / 7 \\
4 / 7\end{array}$ \\
\hline \multirow[t]{2}{*}{33} & \multirow{2}{*}{$\begin{array}{l}\text { Aug. } \\
1967\end{array}$} & & $10^{5.4}$ & 5 & 3 & $7 / 8$ & $5 / 8$ & $1 / 8$ \\
\hline & & & $10^{5.4}$ & 7 & 1 & $4 / 8$ & $4 / 8$ & $2 / 8$ \\
\hline \multirow[t]{2}{*}{43} & $\begin{array}{l}\text { Mar. } \\
1968\end{array}$ & & $10^{5.4}$ & 3 & 8 & $7 / 11$ & $5 / 11$ & $4 / 11$ \\
\hline & May & & $10^{5.4}$ & 5 & 6 & $7 / 11$ & $7 / 11$ & $4 / 11$ \\
\hline 45 & 1968 & & $10^{5.0}$ & 6 & 3 & $7 / 9$ & $6 / 9$ & $5 / 9$ \\
\hline \multicolumn{4}{|c|}{ Total } & 42 & 36 & $\begin{array}{r}47 / 78 \\
(60 \%)\end{array}$ & $\begin{array}{r}38 / 77 \\
(49 \%)\end{array}$ & $\begin{array}{r}32 / 78 \\
(41 \%)\end{array}$ \\
\hline
\end{tabular}

Trials 22(a) and 22(b) took place at the same time. This applies also to 31(a) and $31(b), 33(a)$ and $33(b)$, and $43(a)$ and $43(b)$.

TABLE III-Responses of Volunteers to Different Passes of B/England/ $101 / 62$

\begin{tabular}{|c|c|c|c|c|c|c|c|c|}
\hline \multirow[t]{2}{*}{ Trial } & \multirow[t]{2}{*}{ Date } & \multirow[t]{2}{*}{$\begin{array}{l}\text { Virus } \\
\text { Passage }\end{array}$} & \multirow[t]{2}{*}{$\begin{array}{l}\text { Virus } \\
\text { Dose }\end{array}$} & \multicolumn{2}{|c|}{$\begin{array}{l}\text { Volunteers. } \\
\text { Initial } \\
\text { H.I. Titres } \\
\end{array}$} & \multirow{2}{*}{$\begin{array}{l}\text { Virus } \\
\text { Isola- } \\
\text { tions }\end{array}$} & \multirow{2}{*}{$\begin{array}{l}\text { Anti- } \\
\text { body } \\
\text { Rises }\end{array}$} & \multirow{2}{*}{$\begin{array}{c}\text { Clinical } \\
\text { Reac- } \\
\text { tions }\end{array}$} \\
\hline & & & & $\leqslant 24$ & $>24$ & & & \\
\hline 32 & \multirow{2}{*}{$\begin{array}{l}\text { July } \\
1967 \\
\text { Oct. } \\
1967\end{array}$} & $\mathrm{HU}_{3}{ }^{*}$ & \multirow{6}{*}{$\begin{array}{c}100 \mathrm{Mk} \\
\text { TCD }_{50} \\
10^{2.0}{\stackrel{\text { EID }}{5_{0}}} \\
\text { (a) } 10^{5.0} \\
\text { (b) } 10^{7.0} \\
\text { EID }_{50} \\
10^{6.0} \text { EID }_{50} \\
10^{5.0} \text { EID }_{50} \\
10^{5.5} \text { EID }_{50}\end{array}$} & 6 & 2 & $5 / 8$ & $6 / 8$ & $6 / 8$ \\
\hline 36 & & $\mathrm{E}_{2}$ & & 5 & 2 & $6 / 7$ & $6 / 7$ & $5 / 7$ \\
\hline 37 & \multirow{4}{*}{$\begin{array}{l}\text { Oct. } \\
1967 \\
\\
\text { Dec. } \\
1967 \\
\text { Jan. } \\
1968 \\
\text { Feb. } \\
1968\end{array}$} & $\mathrm{E}_{9}$ & & $\begin{array}{l}4 \\
3\end{array}$ & $\begin{array}{l}2 \\
3\end{array}$ & $\begin{array}{l}2 / 6 \\
3 / 6\end{array}$ & $\begin{array}{l}3 / 6 \\
5 / 6\end{array}$ & $\begin{array}{l}2 / 6 \\
1 / 6\end{array}$ \\
\hline 38 & & $E_{9}$ & & 3 & 3 & $3 / 5$ & $4 / 6$ & $2 / 6$ \\
\hline 39 & & $E_{18}$ & & 4 & 2 & $3 / 6$ & $3 / 6$ & $1 / 6$ \\
\hline 42 & & $E_{30}$ & & 3 & 4 & $3 / 7$ & $3 / 7$ & $2 / 7$ \\
\hline \multicolumn{4}{|c|}{ Total } & 28 & 18 & $\begin{array}{r}25 / 45 \\
(56 \%)\end{array}$ & $\begin{array}{r}30 / 46 \\
(65 \%)\end{array}$ & $\begin{array}{r}19 / 46 \\
(41 \%)\end{array}$ \\
\hline
\end{tabular}

Mk $\mathrm{TCD}_{\mathrm{s}_{0}}=50 \%$ monkey kidney tissue culture doses. Trials 37(a) and 37(b)

took place at the same time.
$*$ Only 8 of the 15 volunteers in Table IV are given here, as laboratory data of the remainder are in some respects incomplete. 
TABLB IV.-Clinical Responses of Volunteers to B/England/101/62 After Human Passage

\begin{tabular}{|c|c|c|c|c|c|c|c|c|}
\hline \multirow{2}{*}{\multicolumn{2}{|c|}{$\begin{array}{c}\text { No. of } \\
\text { Human } \\
\text { Passes of } \\
\text { B/Eng/101/62 }\end{array}$}} & \multirow{2}{*}{$\begin{array}{c}\text { Virus } \\
\text { Dose in } \\
M k \\
\text { TCD }_{50} \\
\end{array}$} & \multicolumn{2}{|c|}{$\begin{array}{c}\text { Volunteers. } \\
\text { Initial H.I. Titres } \\
\end{array}$} & \multirow{2}{*}{$\begin{array}{l}\text { Virus } \\
\text { Isola- } \\
\text { tions }\end{array}$} & \multicolumn{3}{|c|}{ Clinical Reactions } \\
\hline & & & $\leqslant 24$ & $>24$ & & $\frac{\text { Severe }}{1 / 11}$ & $\begin{array}{c}\text { Moderate } \\
\text { or Mild }\end{array}$ & $\begin{array}{r}\text { None } \\
5 / 11\end{array}$ \\
\hline $\begin{array}{l}\text { One } \\
\text { Two } \\
\text { Three }\end{array}$ & $\begin{array}{l}\cdots \\
\ldots \\
\cdots\end{array}$ & $\begin{array}{c}200 \\
100-200 \\
100\end{array}$ & \begin{tabular}{|c} 
Not \\
known \\
24 \\
15
\end{tabular} & $\begin{array}{c}\text { Not } \\
\text { known } \\
1 \\
0\end{array}$ & $\begin{array}{l}\text { Not } \\
\text { known } \\
16 / 25 \\
10 / 15\end{array}$ & $\begin{array}{l}1 / 11 \\
3 / 25 \\
7 / 15\end{array}$ & $\begin{array}{l}5 / 11 \\
5 / 25 \\
3 / 15\end{array}$ & $\begin{array}{r}5 / 11 \\
17 / 25 \\
5 / 15\end{array}$ \\
\hline & & \multicolumn{3}{|c|}{ Total } & $26 / 40$ & $11 / 51$ & $13 / 51$ & $27 / 51$ \\
\hline
\end{tabular}

The three viruses produced infections, stimulated antibody formation, and caused clinical symptoms irrespective of the number of egg passages they had received. In the case of two of the viruses, $A_{2} /$ Leningrad/4/65 and $B /$ England $/ 13 / 65$, early and late passes given in the same trials produced almost identical effects (trial 34, Table I ; trial 31, Table II) ; and after 30 egg passes these viruses were still not attenuated (trial 41 , Table I ; trial 45, Table II). The third virus, B/England/ $101 / 62$ infected volunteers and produced reactions after 20 passes (trial 42, Table III). There was therefore no evidence that the viruses were being attenuated by prolonged serial passage in eggs. Nor was there any indication that pools of virus of the later passages contained a higher proportion of particles non-infective to man than those of the earlier passages. When $B /$ England/13/65 was propagated in parallel series by low and limit dilution inocula, twentieth egg passages obtained by the two methods did not induce noticeably different effects in volunteers (trials 33 and 43, Table II); and there seemed to be little suggestion of a tendency towards the selection of attenuated mutants during egg passage.

While little change in virulence was observed during passage of $\mathrm{A}_{2} /$ Leningrad $/ 4 / 65$ and $\mathrm{B} /$ England $/ 13 / 65$, definite if limited changes occurred in B/England/101/62 (Tables III and IV). After three human passes the clinical symptoms induced by this virus were mainly severe, though in its original state the virus had in most cases caused only mild reactions (Table IV). This result is statistically significant. During adaptation to eggs, the pathogenicity of the virus for man was reduced as it gradually acquired the ability to grow in eggs. However, the change did not progress, and the later egg passes remained relatively virulent (trials $37,38,39$, and 42 , Table III). The series of trials performed with this virus also exemplifies the difficulty often experienced in trying to express doses of influenza viruses for man in $\mathrm{EID}_{50}$. These egg-infecting doses bear a constant relation to human infecting doses only when the virus is fully egg-adapted. In the form of nasal washings $\mathrm{B} /$ England/101/62 had had no infectivity titre in eggs, and at that stage was at the height of its human virulence (trial 32, Table III). It is also of interest to note that once the infecting threshold had been crossed the effects produced in man apparently could not be enhanced by increasing the virus dose. Thus a hundredfold difference did not increase the incidence of infections or of clinical reactions (trial 37, Table III).

Zhdanov and Ritova (1963) stated that their subjects experienced more clinical reactions in winter than in summer. Presumably this was thought to be a climatic effect, and, since the climates of Russia and Great Britain are very different, a strictly comparable study in this country may be impracticable. Nevertheless, influenza in Great Britain has a well-defined seasonal incidence, and an analysis has therefore been made of clinical reactions at different times of the year (Table V). The data are unavoidably fragmentary and uneven. Evidently the Russian virus caused more reactions in winter, but this cannot be said of the English viruses. However, when the same virus inocula of B/England/13/65 were given in August and in March (trials 33 and 43, Table II) the incidence of reactions was $19 \%$ and $36 \%$ respectively. There was also a high infection rate in winter among people with considerable titres of circulating antibody. It is clear, however, that there was no difficulty in infecting volunteers with any of the viruses outside the so-called influenza season.
TABle V.-Possible Seasonal Differences in the Incidence of Clinical Reactions (Zhdanov and Ritova, 1963)

\begin{tabular}{|c|c|c|c|c|}
\hline \multirow[b]{2}{*}{ Virus } & \multicolumn{2}{|c|}{1 May-30 September } & \multicolumn{2}{|c|}{1 October-30 April } \\
\hline & $\begin{array}{l}\text { No. of } \\
\text { Trials }\end{array}$ & $\begin{array}{c}\text { Incidence of } \\
\text { Clinical Reactions }\end{array}$ & $\begin{array}{l}\text { No. of } \\
\text { Trials }\end{array}$ & $\begin{array}{c}\text { Incidence of } \\
\text { Clinical Reactions }\end{array}$ \\
\hline $\begin{array}{l}\mathrm{A}_{2} / \text { Leningrad/4/65 } \\
\mathrm{B} / \text { England/101/62 } \\
\mathrm{B} / \text { England/13/65 }\end{array}$ & $\begin{array}{l}3 \\
1 \\
5\end{array}$ & $\begin{array}{c}4 / 35(11 \%) \\
6 / 8(75 \%) \\
21 / 48(44 \%)\end{array}$ & $\begin{array}{l}2 \\
5 \\
2\end{array}$ & $\begin{array}{l}10 / 14(71 \%) \\
13 / 38(34 \%) \\
11 / 30(37 \%)\end{array}$ \\
\hline
\end{tabular}
Numerato.
observed.

\section{Discussion}

Previous results obtained by ourselves (McDonald et al., 1962 ; Beare et al., 1968) and those of numerous Russian workers had indicated that live influenza vaccines exert a potent protective influence, and the present investigation was undertaken to acquire information on methods of selection and attenuation of viruses. It had already been found that the Iksha strain of $A_{2}$ virus lost its infectivity for man after relatively few passes in the laboratory (Beare et al., 1967). In view of the results obtained in the present investigation this must be considered to have been a freak event. After numerous egg passes an Asian virus and two influenza $B$ viruses with originally dissimilar capacities for growth in embryonated eggs showed little change in their human pathogenicity and infectivity. Zhdanov (1967) stated that egg passage quickly abolishes pathogenicity for man and that infectivity, after being retained for a while, is also soon lost. We could not reproduce this pattern of attenuation in 30 successive egg passes at $33^{\circ} \mathrm{C}$., and it seems that under ordinary conditions of handling in the laboratory and without deliberate efforts to induce mutations, influenza viruses are just as stable in regard to human pathogenicity and infectivity as they appear to be in other respects.

A naturally occurring relatively avirulent influenza $B$ virus acquired enhanced virulence after human passage. This was subsequently reduced by a few passes in the chick embryo. However, the effect was very limited and there was little further attenuation after numerous egg passes. The investigation as a whole apparently extends to man the original observation that influenza viruses which are virulent in ferrets and mice remain so after prolonged propagation in eggs, although their virulence may be increased to a limited extent by further passage in these animals.

No attempt has been made on this occasion to link the behaviour of the viruses in man with their laboratory characteristics. Some success had previously been achieved on this particular aspect of the problem with the Iksha virus (Beare et al., 1967 ; Hobson et al., 1967). This remains, however, a crucial part of the subject of living influenza vaccines and will need to be studied thoroughly before viruses can be recommended for mass immunization.

We are indebted to Dr. P. G. Higgins and Professor A. A. Smorodintsev for viruses and to Dr. A. J. Beale of Glaxo Ltd. for supplies of leucosis-free eggs. We also thank Miss M. D. Turnbull, S.R.N., for help with the clinical surveillance and the volunteers for their willing co-operation. We are particularly grateful to Miss P. D. Ball for invaluable technical assistance. The unit receives a grant from the World Health Organization.

\section{REFERENCES}

Beare, A. S., et al. (1967). f. Hyg. (Lond.), 65, 245.

Beare, A. S., et al. (1968). f. Hyg. (Lond.). In

Burnet, F. M., and Bull, D. R. (1943). Aust. f. exp. Biol. med. Sci., 21,

Hobson, D., Gould, E. A., and Flockton, H. I. (1967). F. Hyg. (Lond.), $65,255$.

McDonald, J. C., Zuckerman, A. J., Beare, A. S., and Tyrrell, D. A. J. (1962). Brit. med. ₹., 1, 1036 .

Tyrrell, D. A. J. (1963). Amer. Rev. resp. Dis., 88, No. 3, part 2, 128. Zhdanov, V. M. (1967). Proceedings of first International Conference on Vaccines against Viral and Rickettsial Diseases of Man, held in Waccines against Viral and Rickettsial

Zhdanov, V. M., and Ritova, V. V. (1963). Fed. Proc., 22, T800.

Zhdanov, V. M., Ritova, V. V., Orlova, A. V., Sokolova, N. N., and Golygina, L. A. (1957). Lancet, 2, 735. 